\title{
A. Odrzywolska-Kidawa, Podkanclerzy Piotr Tomicki 1515- 1535. Polityk i humanista, Wydawnistwo Naukowe Semper, Warszawa 2005, ss. 304.
}

Współczesna historiografia widzi konieczność powrotu historyków do badań początków XVI stulecia w Polsce. W XX wieku powstały prace między innymi: A. Dembińskiej, W. Dworzaczka, L. Finkla, O. Haleckiego, L. Kolankowskiego, J. Kurtyki, W. Pociechy, A. Sucheni-Grabowskiej, W. Uruszczaka, Z. Wojciechowskiego, A. Wyczańskiego jednak zdecydowana większość z nich jeszcze przed II wojną światową ${ }^{1}$. Współcześni badacze zajmujący się pierw-

\footnotetext{
1 Najważniejsze spośród wielu ważnych prac to: A. Dembińska, Polityczna walka o egzekucje dóbr królewskich w latach 1559/1564, Warszawa 1935; A. Dembińska, Zygmunt I. Zarys dziejów wewnatrzpolitycznych w latach 1540-1548, Poznań 1948; W. Dworzaczek, Hetman Jan Tarnowski. Z dziejów możnowładztwa małopolskiego, Warszawa 1985; W. Dworzaczek, Leliwici Tarnowscy. Z dziejów możnowładztwa małopolskiego. Wiek XIV-XVI, Warszawa 1971; L. Finkel, Elekcja Zygmunta I, Kraków 1910; O. Halecki, Dzieje unii jagielonskiej w XVI wieku, Kraków 1920; O. Halecki, Idea Jagiellońska, Lwów 1937; K. Hartleb, Działalność kulturalna biskupa-dyplomaty Erazma Ciołka, Lwów 1929; K. Hartleb, Jan Zambocki; dworzanin i sektetarz J.K.M., Warszawa 1937; J. Kieszkowski, Kanclerz Krzysztof Szydłowiecki. Z dziejów kultury i sztuki zygmuntowskich czasów, t. 1-2, Poznań 1912; L. Kolankowski, Polska Jagiellonów. Dzieje polityczne, Lwów 1936; J. Kurtyka, Latyfundium Tęczuńskich. Dobra i wtaściciele w XIV-XVII wieku, Kraków 1999; Idem, Tęczyńscy. Studium z dziejów polskiej elity moźnowładczej w średniowieczu, Kraków 1997; F. Papee, Aleksander Jagiellończyk, Kraków 1949; Idem, Jan Olbracht, Kraków 1936; W. Pociecha, Geneza hołdu pruskiego (1476-1525), Gdynia 1937; Idem, Królowa Bona 1494-1557. Czasy i ludzie odrodzenia, t. 1-2, Poznań 1949; Idem, Królowa Bona 1494-1557. Czasy i ludzie odrodzenia, t. 3-4, Poznań 1958; A. Sucheni-Grabowska, Zygmunt August. Król Polski i Wielki Ksiaze Litewski 1520-1562, Warszawa 1966; W. Uruszczak, Korektura praw z 1532 roku. Studium historycznoprawne, t. 1, ZNUJ, „Prace Prawnicze”, t. CMLXVI, z. 135, Warszawa - Kraków 1990; t. II, ZNUJ, „Prace Prawnicze”, t. MIII, z. 137, Warszawa - Kraków 1991; Idem, Próba kodyfikacji prawa polskiego w pierwszej połowie XVI wieku. Korektura praw z 1532 roku, Warszawa 1979; Idem, Sejm walny koronny 1506-1540, Wrocław 1981; Z. Wojciechowski, Hołd pruski i inne studia historyczne, Poznań 1946; Idem, Zygmunt Stary, Warszawa 1946; A. Wyczański, Francja wobec państw jagielloniskich w latach 1515-1529, Wrocław 1954; Idem, Między kulturq a polityka. Sekretarze królewscy Zygmunta I (1506-1548), Warszawa 1990; Idem, Polska Rzecza pospolita szlachecka, Warszawa 1991; Idem, Szlachta polska w XVI wieku, Warszawa 2001; Idem, Zygmunt Stary, Warszawa 1985.
} 
szą połową XVI wieku wskazują na całą gamę postulatów badawczych, które powinny uzupełnić stan naszej wiedzy.

W 2005 roku pojawiła się, nakładem wydawnictwa naukowego Semper, ważna pozycja Anny Odrzywolskiej-Kidawy pt. Podkanclerzy Piotr Tomicki 1515-1535. Polityk i humanista ${ }^{2}$. Jak można zauważyć, Autorka wpisuje się tą pracą w krąg opracowań podejmujących tematykę elity możnowładczej pierwszej połowy XVI wieku.

$\mathrm{Z}$ drugiej strony Autorka przywołanej pracy jest jednym z nielicznych współczesnych historyków, którzy w swoich badaniach zajmują się okresem Zygmunt I. Dodać należy, iż recenzowana książka nie jest pierwszą publikacją Autorki, poruszającą szerokie spektrum problemów, głównie życia politycznego, kulturalnego, społecznego elity możnowładczej Korony na przykładzie wybitnej postaci tej epoki - Piotra Tomickiego ${ }^{3}$. Omawiana praca stanowi dopełnienie poprzedniej, pochodzącej z 2004 roku, książki pod tytułem Biskup Piotr Tomicki (1464-1535). Kariera polityczna i kościelna, która również ukazała się nakładem wydawnictwa Semper.

Mimo iż historiografia doczekała się kilku tekstów poświęconych sylwetce biskupa i podkanclerzego, to z pewnością nie wyczerpały one tematu, a część z nich w pełni się zdezaktualizowała ze względu na nowe badania ${ }^{4}$. Dzięki więc

2 A. Odrzywolska-Kidawa, Podkanclerzy Piotr Tomicki. Polityk i humanista 1515-1535, Warszawa 2005.

3 Wśród prac Anny Odrzywolskiej-Kiddawy na szczególą uwagę zasługują: A. Odrzywolska-Kidawa, Biskup Piotr Tomicki (1464-1535). Kariera polityczna i kościelna, Warszawa 2004; Eadem, Krag rodzinny biskupa Piotra Tomickiego, „Studia Historyczne” r. XLIV, 2001, z. 4; Eadem, Przyczynek do polityki Jana Olbrachta wobec wielkich miast pruskich, ,Prace Naukowe Wyźszaj Szkoły Pedagogicznej w Częstochowie”, Seria: Zeszyty Historyczne, 1998, z. 5; Eadem, U źródet kariery urzędniczej Piotra Tomickiego, „Biuletyn Instytutu Filozoficzno-Historycznego”, Wyższa Szkoła Pedagogiczna w Częstochowie, nr 32 (10), 2003; Eadem, Zabiegi Piotra Tomickiego o biskupstwo przemyskie, „Biuletyn Instytutu Filozoficzno-historycznego”, Wyższa Szkoła Pedagogiczna w Częstochowie, nr 28 (8), 2001; A. Odrzywolska-Kidawa, Znaczenie związów rodzinnych w karierze (na przykładzie biskupa Piotra Tomickiego i jego siostrzeńca Andrzeja Krzycckiego), „Prace Naukowe Wyższej Szkoły Pedagogicznej w Częstochowie”, Seria: Zeszyty Historyczne, 2003, z. 7, Prace i materiały ofiarowane Prof. Andrzejowi J. Zakrzewskiemu w 60-tą rocznicę urodzin, red. M. Antoniewicz i M. Cetwiński.

4 J. Bartoszewicz, Piotr Tomicki biskup krakowski, „Tygodnik Ilustrowany” t. VIII, 1863; S. Brzeziński, Biskup podkanclerzy Piotr Tomicki na tle swej epoki, „Przegląd Powszechny” 51, t. 202, 1934; A. Kidawa Błońska, Krag rodzinny biskupa Piotra Tomickiego, „Studia Historyczne”, 2001, z. 4; E. Stańczak, Piotr Tomicki jako przedstawiciel ideologii magnackiej Polski w XVI wieku, Lublin 1954, mps; W. Urban, Działalność sqadownicza Piotra Tomickiego jako biskupa krakowskiego (1524-1535), w: Kościót katolicki w Małopolsce w średniowieczu i we wczesnym okresie nowożytności, pod red. W. Kowalskiego i J. Muszyńskiej, Kielce - Gdańsk 2001; A. Wyczański, Szkic do sylwetki humanisty-polityka. Rzecz o Piotrze Tomickim, w: Ludzie, kontakty, kultura XVI-XVIII wieku. Prace ofiarowane profesor Marii Boguckiej, Warszawa 1997. 
solidnej pracy opartej na rzetelnych badaniach czytelnik otrzymuje nowe spojrzenie na problematykę nie tylko życia Piotra Tomickiego, ale w ogóle kwestii społecznych, politycznych, kulturalnych pierwszej połowy XVI wieku w Koronie.

Recenzowana pozycja liczy 304 strony, podzielona została na pięć rozdziałów, a każdy z nich na cztery lub pięć podrozdziaów. Istotnym walorem pracy jest baza źródłowa, na której zostały oparte badania (podzielona na: rękopisy, źródła drukowane i litertaturę przedmiotu).

Autorka stanęła przed ogromną spuścizną, jaką pozostawił po sobie Piotr Tomicki, a to wymusiło dokonanie selekcji materiału źródłowego, na który składają się: listy, akta biskupie, akta kapitulne, rękopisy biblioteczne. Całość źródeł prezentuje się rzeczywiście imponująco i świadczy o ogromie pracy, jaką wykonała Autorka. Zwraca uwagę rzetelność, z jaką uczona podeszła do problemów badawczych, jakie sama postawiła przed sobą we wstępie omawianej pracy. Najważniejsze z nich to: próba określenia stosunku Tomickiego do najważniejszych problemów politycznych w Koronie, zbadanie sposobu, w jaki podkanclerzy realizował zadania zlecane mu przez króla, czy realizował własne inicjatywy?, kiedy następowała intensyfikacja jego aktywności politycznej?, dlaczego w pewnym momencie utracił wpływy na dworze królewskim?

Konstrukcja pracy nie budzi zastrzeżeń, chociaż zaznaczyć należy, że dziwi proporcja i stosunek problematyki politycznej (cztery rozdziały) do kulturalnej (jeden rozdział). Nie bardzo wiadomo dlaczego, dysproporcja jest tak znaczna, sama Autorka nie odnosi się do tego w żadnym miejscu, a podtytuł „Polityk i humanista" sugeruje nam, iż powinna być jednak zachowana pewna równowaga. Po drugie szkoda, iż ta dysproporcja jest tak znaczna, gdyż wielokrotnie można mieć wrażenie, iż Autorka doskonale porusza się w problematyce związanej z szeroko rozumianą kulturą. Natomiast pewne interpretacje związane z polityką wewnętrzną państwa, zwłaszcza w odniesieniu do problematyki funkcjonowania szlachty koronnej w życiu publicznym budzą pewne zastrzeżenia. Szkoda, gdyż powoduje to że do tej bardzo dobrej i ważnej pracy wkradają się uproszczenia, sprawiające iż książka jest nierówna. Obok rozdziałów i podrozdziałów bardzo dobrych (pierwszy, trzeci, piąty) pojawiają się i nieco słabsze (drugi, zwłaszcza podrozdział drugi i trzeci).

W pierwszym interesującym rozdziale (str. 15-51) poświęconym omówieniu elity możnowładczej skupionej wokół panującego Autorka koncentruje się na zaprezentowaniu i omówieniu koncepcji politycznych Zygmunta I i jego żony królowej Bony oraz roli i znaczeniu Piotra Tomckiego w tym układzie politycznym. Interesujące, iż badaczka stara się odpowiedzieć na pytanie - co świadczyło o elitarności i mogło wpłynąć na przynależność do kręgu najbliższych współpracowników monarchy? Oprócz tego prezentuje główne założenia polityki królewskiej, w tym ważnym dla dziejów politycznych Korony okresie. Tym bardziej, że jest to czas, w którym do głosu powoli dochodzi średnia szlachta skupiona wokół haseł, określanych mianem egzekucji praw i dóbr. Warto pamiętać, iż 
był to dojrzały program polityczny zakładający między innymi zmianę układu sił w państwie i przeniesienie punktu ciężkości z możnowładztwa na szlachtę w odniesieniu do zaplecza monarchy w bieżącej polityce. Sytuację komplikowała jeszcze sama królowa Bona kształtująca własny program polityczny i środowisko możnych skupionych wokół tych idei.

W pracy pojawia się interesujący wątek, w którym Autorka zauważa, iż skład grupy rządzącej za panowania Zygmunta I ulegał zmianom i przeksztaceniom w ciągu ponad czterdziestoletniego okresu rządów przedostatniego Jagiellona, ale była też stała grupa kilku najbliższych i najbardziej zaufanych współpracowników króla. Wśród nich znajdował się przez bardzo długi okres Piotr Tomicki.

Warto odnieść się do tezy zaprezentowanej w pierwszym podrozdziale omawiającym elitę ówczesnej władzy, gdzie Autorka precyzuje i dokonuje systematyki terminologii określającej grupy możnych skupionych wokół określonych idei, nazywając je - „grupami interesu”, a nie stronnictwami czy partiami (str. 16). W interesujący sposób prezentuje ścieranie się różnych poglądów w gronie możnowładztwa, co pozostawało nie bez znaczenia dla siły politycznej tej grupy.

Podrozdział drugi rozprawia się ze stereotypem Zygmunta I jako króla senatorskiego - opinii dosyć powszechnej w historiografii polskiej. Słusznie zauważa Autorka, że model rządzenia (w czasie podkanclerstwa Piora Tomickiego) opierał się na przewadze senatu, ale najważniejsze decyzje zapadały w gronie najbliższych doradców króla (str. 30). Warto w tym miejscu przypomnieć to, na co zwraca uwagę Autorka - na stały proces polegający na zmianie układu sił w państwie w ostatnim dziesięcioleciu panowania Zygmunta Starego, kiedy do głosu dochodzi program średnioszlachecki, w którym postulaty tej grupy były coraz bardziej precyzyjnie formułowane. A tym samym wydarzenia $\mathrm{z}$ lat 1537-1538 słusznie według Autorki uświadomiły królowi i królowej, iż taki model sprawowania władzy nie jest w stanie funkcjonować w dłuższej perspektywie (str. 30).

Nie znaczy to, że Zygmunt Stary zmienił w oparciu o te wydarzenia strategię rządów, wyraźnie widać, że drażnił go sposób manifestowania swoich poglądów przez przywódców średnoszlacheckich, gdyż uważał ograniczenie władzy królewskiej za czynnik, który paraliżuje skuteczne rządzenie państwem (str. 31).

Trudno natomiast zaakceptować przedstawioną przez A. Odrzywolską-Kidawę tezę o tym, iż w kwestii stosunków z Turcją, Korona chciała pełnić rolę „antymurale christianitatis”. Jest to co najmniej kwestia dyskusyjna, której sporo miejsca poświęcono w historiografii polskiej przełomu XIX-XX wieku5. Dziś

5 Warto przypomnieć, w jaki sposób historiografia romantyczna rozprawiała się z tym problemem. Otóż podkreślano (np. Adam Mickiewicz), iż duch chrześcijański przewodził naszym dziejom, a Polska ze względu na położenie geopolityczne musiała wziąć na siebie ciężar obrony cywilizacji chrześcijańskiej przed wyznawcami islamu (Mongołami i Turkami). Oprócz tego w łonie samego chrześcijaństwa nastąpił rozłam, w wyniku którego ukształtowały się dwa odmienne typy ustrojowe i kulturowe. Oczywiście Mickiewicz nie był jedynym głoszącym ideę Polski jako 
wyżej przedstawiony pogląd wydaje się nie do przyjęcia zwłasza w odniesieniu do pierwszej połowy XVI wieku (str. 35).

Interesujący natomiast jest wywód Autorki na temat funkcjonowania tzw. „ideii jagiellońskiej” kształtującej ówczesną rzeczywistość. Pewne interpretacje badaczki w tej materii wydają się jednak zbyt ogólne, zwłaszcza kiedy stwierdza, iż idea ta nie została potwierdzona przez pogorszenie stosunków politycznych z Czechami i Węgrami. Wydaje się, że jest to pogląd nieuzasadniony, gdyż problem ten jest dużo bardziej złożony i nie da się go zamknąć w tak nieprecyzyjnym stwierdzeniu (str. 35).

Ciekawie prezentuje Autorka stosunek Tomickiego do królowej Bony i jej programu politycznego (podrozdział Stosunek do królowej Bony). Małżeństwo króla otworzyło nowy etap w polityce wewnętrzej i zagranicznej państwa, co nie było bez znaczenia dla pozycji Piotra Tomickiego (str. 38). Tym bardziej, że polityka królowej doprowadziła w ostatniej fazie panowania Zygmunta Starego do odsunięcia czołowego stronnika królewskiego od życia publicznego i jego marginalizację, z czym nie pogodził się on do końca swego życia. Natomiast królowa w zaistniałej sytuacji upatrywała nowych możliwości dla siebie, zwłaszcza w odniesieniu do najważniejszych spraw państwowych. Tomicki w zasadzie do końca swoich dni zabiegał o polepszenie stosunków z parą królewską, działania te nie spotkały się jednak z pozytywnym zakończeniem (str. 48).

W tym analizowanym podrozdziale razi tylko stwierdzenie Anny Odrzywolskiej-Kidawy, w którym umieszcza Władysława Pociechę wśród przedstawicieli najnowszej polskiej historiografii ${ }^{6}$. Doceniając wkład, jaki wniósł ten wybitny uczony do nauki polskiej, nie powinno się jednak utożsamiać go ze

przedmurza (religijnego i cywilizacyjnego Europy). Wśród historyków koncepcja ta była wysuwana przez m.in. Karola Boromeusza Hoffmana Badacz ten, zaliczając Polskę do go grona narodów zachodnich, stanowczo odcinał ją od cywilizacji wschodniej. Co więcej, skłonny był traktować dzieje Polski w aspekcie cywilizacyjnego przedmurza. Była to tzw. idea ,panslawizmu zachodniego". Patrz A. Wierzbicki, Wschód-Zachód w koncepcjach dziejów Polski, Warszawa 1984, s. 211; M. H. Serejski, Naród a państwo w polskiej myśli historycznej, Warszawa 1973, ss. 135, 165. Problematyką antemurale zajmowali się też J. Tazbir, Od antemurale do przedmurza, dzieje terminu, „Odrodzennie i reformacja w Polsce”, t. XXIX, 1984, s. 167-184; Idem, Przedmurze jako miejsce Polski w Europie, w: Rzeczypospolita i świat. Z dziejów kultury XVII wieku, Wrocław 1971; H. Olszewski, Ideologia Rzeczypospolitej - przedmurza chrześcijaństwa, „Czasopismo Prawno-Historyczne”, t. 2, 1983; J. Wimmer, Wiedeń 1683. Dzieje kampanii i bitwy, Warszawa 1983, s. 23-24; J. Maciszewski, Szlachta polska i jej państwo, Warszawa 1969, s. 188. Bardzo ważny głos w dyskusji zabrał też J. Urwanowicz, Wokót ideologii przedmurza chrześcijaństwa w Rzeczypospolitej w drugiej połowie XVI wieku, „Odrodzenie i reformacja w Polsce”, t. XXIX, 1984, s. $185-199$.

6 A. Odrzywolska-Kidawa, Podkanclerzy Piotr Tomicki. Polityk i humanista 1515-1535, s. 38. Najnowsza historiografia $-z$ Władystawem Pociecha na czele - doceniła gruntowne wykształcenie, energię, zmyst polityczny $i$ działalność gospodarczą. Patrząc na daty najważniejszych dzieł W. Pociechy, sformułowanie to nie wydaje się najtrafniejsze. W. Pociecha, Czasy Zygmunta Starego, „Rocznik Historyczny”, t. 16, 1947; Idem, Geneza hołdu pruskiego (1476-1525), Gdynia 
współczesną grupą badaczy podejmujących się pracy nad problematykę panowania Zygmunta I.

W rozdziale drugim książki, który został poświęcony dwóm ważnym zagadnieniom: funkcjonowaniu kancelarii królewskiej i sejmu w latach 1505-1548, Autorka w sposób niezwykle rzetelny i precyzyjny zaprezentowała zasługi Piotra Tomickiego dla stworzenia nowożytnej kancelarii, która prezentowała bardzo wysoki poziom - porównywalny z tego typu instytucjami w Europie (str. 52).

Inaczej przedstawia się sprawa funkcjonowania sejmu walnego $\mathrm{w}$ omawianym okresie zwłaszcza, że - jak zaznacza Autorka - nie dysponujemy diariuszami sejmowymi (doskonałym źródłem), a jedynie aktami normatywnymi i urzędowymi oraz korespondencją polityczną. Już na wstepie tego rozdziału badaczka zastrzega się, iż taki stan ...dopuszcza subiektywna ocenę sytuacji (str. 52). Nie wdając się w dyskusję nad subiektywnością i obiektywnością w badaniu historycznym i ocenie wartości wyżej wymienionych źródeł, wypada stwierdzić, iż jest to jedna z najsłabszych części recenzowanej pozycji. W tezach Autorki dominuje w zasadzie dostępny stan badań w tym zakresie (przede wszystkim wykładnia W. Uruszczaka), brak natomiast, moim zdaniem, refleksji i próby głębszego poznania tej problematyki.

Warto też dodać, iż Anna Odrzywolska-Kidawa nie podejmuje próby odpowiedzi na fundamentalne pytanie - czy możnowładztwo koronne dysponowało jednym, konkretnym programem politycznym? Jeżeli tak, to jaki był stosunek P. Tomickiego do tego typu idei i postulatów? Jest to zagadnienie interesujące, ważne z punktu widzenia życia politycznego państwa i w gruncie rzeczy nie do końca zbadane.

Tomicki, jako posłuszny wykonawca woli monarszej, prezentował tożsamą z linią królewską wizję dotyczącą udziału szlachty w życiu publicznym. Najchętniej na forum sejmu widziałby posłów ...którzy nic nie uczyniq na sejmie bez rady naszej (str. 79). Pogląd to osobliwy, biorąc pod uwagę czas, kiedy te słowa zostały sformułowane. Dowodzi to moim zdaniem braku własnej oceny i refleksji podkanclerzego w stosunku do bieżącej sytuacji politycznej, na co często zwraca uwagę Autorka, wskazując iż wielokrotnie trudno jest badając spuściznę po Tomickim, z całą mocą rozstrzygnąć, które opinie i poglądy są tylko i wyłącznie podkanclerzego, a które stanowią królewski pogląd. Jest to o tyle istotne, gdyż Piotr Tomicki był obecny na wszystkich sejmach, w któ-

1937; Idem, Kokosza wojna (1537), w: Wielka Ilustrowana Encyklopedia Powszechna (Gutenberga), t. VIII, Kraków 1930; Idem, Królowa Bona 1494-1557. Czasy i ludzie odrodzenia, t. 1-2, Poznań 1949; Idem, Królowa Bona 1494-1557. Czasy i ludzie odrodzenia, t. 3-4, Poznań 1958; Idem, O zjeździe w Poznaniu w roku 1530, „Pamiętnik Biblioteki Kórnickiej”, t. 4, 1974; Idem, Walka sejmowa o przywileje Kościoła w Polsce w latacha 1520-1537, „Reformacja w Polsce” II, 1922; Idem, W sprawie wydawnictwa Actów Tomicjanów, „Pamiętnik Biblioteki Kórnickiej” t. 3, Kórnik 1939-1946. 
rych uczestniczył też Zygmunt Stary (str. 80). Była to obecność czynna, gdyż podkanlerzy często przemawiał na forum izby poselskiej i senatu, a na sejmie w 1529 roku reprezentował nieobecnego króla, do czego upoważniały go listy uwierzytelniające. Zawsze, gdy zabierał głos, wyrażana opinia i pogląd były wcześniej uzgadniane z monarchą (str. 81). Wystąpienia szlacheckie utożsamiał Tomicki z inspiracją możnych, którzy, wykorzystywali tę grupę społeczną i tym samym osłabili pozycję króla w państwie (str. 88). Warto byłoby jednak zastanowić się, czy sprawa ta może być interpretowana tylko w taki sposób - interesujące czy nie był to już program polityczny szlachty, którego być może Tomicki nie rozumiał, skoro wszelkie przejawy samodzielności politycznej szlachty traktował jako zakłócanie sprawnego przebiegu obrad sejmowych. Natomiast w pełni akceptował zwyczaj wywierania nacisku na posłów w czasie nieoficjalnych spotkań po to, aby uzyskać pewność, iż podczas obrad poprą oni propozycje tronu (str. 86). Podobną opinię prezentował też pisarz Tomickiego Stanisław Górski.

Co najmniej dyskusyjna wydaje się opinia Autorki, która tłumaczy problemy z wprowadzeniem w życie reform skarbowo-wojskowych niewłaściwym systemem skarbowości i koniecznością systematycznego odwoływania się monarchy do sejmu w sprawie uchwalania i nakładania nowych podatków, co według niej, osłabiało zakres inicjatyw królewskich. Mimo to możemy przeczytać ...Zygmuntowi I udawało się egzekwować od szlachty uchwały poborowe na opłacenie wojska (str. 87). Szkoda, że Autorka nie postarała się o głębszą analizę i nie zwóciła uwagi na drugą, bezpośrednio zainteresowaną nowymi obciążeniami podatkowymi stronę. Nie odpowiada też na pytanie, co takiego powodowało, iż mimo wszytko król potrafił „nakłaniać” szlachtę do uiszczania wspomnianych opłat.

Polemiczna wydaje się też wielokrotnie podkreślana przez Autorkę teza o tym, że Tomicki (oraz spora część możnych) manipulował szachtą, korzystając z jej ...siły politycznej do osiagnięcia własnych celów (str. 88). Warto byłoby w obliczu takich informacji zadać nasuwające się pytanie - na ile szlachtą rzeczywiście manipulowano, a na ile to ona prowadziła własną grę polityczną? Pytanie to pozostaje na razie otwarte, co nie znaczy, że nauka nie powinna zajać określonego stanowiska w tej sprawie. Na potwierdzenie tej tezy można by przytoczyć słowa samego Zygmunta I, który w 1523 roku stwierdził Nam zawsze wydawato się to bardzo zgubnym, że nasi senatorowie, baczac na wzajemne wspótzawodnictwa $i$ sprawy prywatne, $z$ dnia na dzień coraz więcej podnosili znaczenie społeczności szlacheckich $w$ radzie Rzeczypospolitej. Przewidywaliśmy bowiem, że to wyjdzie na obnizenie powagi naszej $i$ senatu... $i$ wielka szkoda Rzeczypospolitej, do czego już doszło, a jeszcze bardziej dojdzie w przyszłości, tak że jeżeliby wszyscy razem z nami chcieli temu zapobiec, tego już może nie zdołamy dokonać. Na marginesie dodać można, że taki sam pogląd prezentował Piotr Tomicki (str. 96). 
W bardzo interesujący sposób charakteryzuje Autorka intensyfikację wystąpień szlachty od 1535 roku, zwracając uwagę na powolną, ale znaczącą zmianę układu sił w państwie, zwłaszcza, że konstytucje sejmowe z 1538 roku, które zostały zaprzysiężone przez króla, znacznie ograniczały jego prerogatywy w zakresie nadawania urzędów (str. 99-100). Oprócz tego cechą sejmów po 1535 roku była wyraźna dbałość szlachty o zabezpieczenie własnych praw i przywilejów z równoczesnym kontrolowaniem, aby nie zwiększył się zakres władzy i uprawnień Zygmunta I. To zaś doprowadziło do tego, iż sejmy miały wyjątkowo burzliwy przebieg.

Obszerny rozdział trzeci (Problemy integracji, inkorporacji i unii) prezentuje dokonania Piotra Tomickiego na tym polu. Wydaje się, że rola podkanclerzego była w tym zakresie dosyć poważna, biorąc pod uwagę jego prawdziwe zaangażowanie i działalność obliczoną na uzyskanie wymiernych korzyści dla państwa. Interesująca jest postawa biskupa w stosunku do traktatu krakowskiego, gdyż stwierdza on, że nie było wyraźnych powodów, aby interes państwa podporządować religii, a traktat według niego został zawarty dla dobra Korony (str. 143). Autorka podkreśla też, że sprawę Albrechta Hohenzolerna i sekularyzację Zakonu Piotr Tomicki rozpatrywał w kategoriach racji stanu państwa (str. 145). Ciekawa jest również konkluzja zamykająca problematykę pruską, gdzie badaczka stwierdza, iż winą za taki kształt traktatu należy równomiernie obciążyć króla, senat oraz szlachtę, czyli uczestników sejmu 1524-1525. Jest to o tyle cenne, że tym samym Autorka wpisuje się w poważną i wciąż, jak sądzę, do końca nierozstrzygniętą dyskusję nad oceną traktatu 1525 roku.

Osobnym i słabo opracowanym zagadnieniem jest problem unii Korony z Wielkim Księtwem Litewskim. Już na początku podrozdziału Autorka podkreśla złożoność i wagę problemu, ale $\mathrm{z}$ drugiej strony poświęca tej sprawie ledwie kilkanaście stron, co stanowi znaczną dysproporcję w stosunku do innych kwestii, które zostały potraktowane o wiele szerzej.

W recenzowanej pracy pojawia się interesujący wątek stosunku biskupa Tomickiego do reformacji. Z jednej strony można uznać podkanclerzego za gorliwego przeciwnika nowych idei religijnych, który zaangażował się $\mathrm{w}$ walkę $\mathrm{z}$ innymi w wierze. $Z$ drugiej strony wielokrotnie zauważyć można $w$ jego działaniu wiele tolerancji w stosunku do nowinek religijnych. Według Anny Odrzywolskiej-Kidawy stanowisko Tomickiego można by porównać z wizją i stanowiskiem Erazma z Rotterdamu (str. 236). To nie znaczy, że nie podejmował żadnych działań obliczonych na powstrzymanie rozwoju protestantyzmu w Koronie.

Jednym z najlepszych, choć najkrócej opisanych zagadnienień jest prezentacja sylwetki Tomickiego-humanisty w rozdziale piątym (Nomen Illius Vivens In Aeternum). Czytelnik poznaje kształtowanie się charakteru intelektualnego biskupa oraz rozwój jego osobowości w duchu haseł i idei humanistycznych. Otrzymujemy dzięki temu obraz wybitnej postaci czynnie zaangażowanej w działalość Akademii Krakowskiej, podnoszącej poziom jej nauczania. Kolejnym istotnym 
i sprawnie omówionym zagadnieniem jest kwestia mecenatu Tomickiego. Szkoda tylko, że Autorka podaje małą liczbę przykładów dotyczących dziłalności harytatywnej biskupa.

Jako odrębne postulaty badawcze potraktować można ustępy książki traktujące o rozwoju kolekcjonerstwa w omawianym okresie na przykładzie działalności biskupa krakowskiego. Jest to interesujące zagadnienie słabo zbadane na gruncie polskim ${ }^{7}$ (str. 259).

Podsumowując powyższe rozważania, można by zapytać, czy w świetle omawianej pracy Piotr Tomicki biskup i podkanclerzy posiadał jakiekolwiek wady? Czasami studiując recenzowaną pozycję, można odnieść wrażenie, że nie. Mimo to stwierdzić należy, że był to człowiek z „krwi i kości” i tylko sympatia Autorki w stosunku do głównego bohatera pracy nie pozwalała jej na głębsze eksponowanie wad i niedoskonałości tej postaci. Natomiast podkreślić należy, że jest to bardzo ważna praca, która wnosi odrębne i ważne stanowisko nie tylko dotyczące konkretnej postaci, ale także fnkcjonowania państwa polskiego pierwszej połowy XVI wieku. Drobne i nieliczne dyskusyjne poglądy Autorki w żadnym razie nie umniejszają znaczeniu tego dzieła w dorobku historiografii polskiej, tym bardziej że Anna Odrzywolska-Kidawa nie bała się podejmowania kwestii spornych i drażliwych, zwykle wyrażając swoją opinię na dany temat. A to z kolei wymagało od niej dogłębnego przebadania olbrzymiej ilości źródeł, co umożliwiło nie tylko napisanie biografii tej wybitnej postaci, ale pokazanie szerszego kontekstu historycznego trudnego okresu panowania Zygmunta Starego. Wieloaspektowe potraktowanie tej problematyki pozwoliło na wysunięcie wielu nowych, ważnych postulatów badawczych i zweryfikowanie panujących w literaturze opinii i poglądów.

Jacek Brzozowski Białystok

\footnotetext{
7 Problematyka kolekcjonerstwa w epoce nowożytnej w odniesieniu do Europy Zachodniej została szczegółowo omówiona przez Krzysztofa Pomiana w książce Zbieracze i osobliwości. Paryż - Wenecja XVI-XVIII wiek, Warszawa 1996; vide też Z. Żygulski Jan, Muzea na świecie, Warszawa 1982; A. Bochnak, Mecenat Zygmunta Starego w zakresie rzemiosła artystycznego, „Studia do Dziejów Wawelu", t. 2, 1960,
} 